\title{
PEMODELAN PENENTUAN KREDIT SIMPAN PINJAM MENGGUNAKAN METODE ADDITIVE RATIO ASSESSMENT (ARAS)
}

\author{
Charis Maulana, Aria Hendrawan, Agusta Praba Ristadi Pinem \\ Universitas Semarang, Semarang, Indonesia \\ 1.charis@usm.ac.id, ${ }^{2}$ aria@usm.ac.id, ${ }^{3}$ agusta.pinem@usm.ac.id
}

\begin{abstract}
ABSTRAK
Beberapa koperasi dalam memberikan pinjaman ke anggotanya sangat bergantung pada masing-masing pemberi keputusan dan bobot penilaian yang berbeda untuk setiap kriteria. Berbeda dengan pinjaman di bank, pinjaman pada koperasi memiliki kriteria yang mengacu pada aturan tiap koperasi. Hal ini menjadi menarik untuk dilakukan penelitian dengan menerapkan metode Additive Ratio Assessment dalam suatu sistem pendukung keputusan, sehingga dapat membantu dalam menentukan penerima pinjaman koperasi untuk menghindari kredit macet. Sistem Pendukung Keputusan (SPK) adalah sistem yang dapat membantu seseorang, dalam mengambil suatu keputusan yang akurat dan tepat sasaran. Banyak permasalahan yang dapat diselesaikan dengan menggunakan SPK, contohnya membangun model sistem pendukung keputusan penentuan anggota koperasi potensial dalam pengajuan pinjaman untuk menghasilkan informasi anggota koperasi potensial untuk menghindari kredit macet.
\end{abstract}

Kata kunci: Sistem Pendukung Keputusan, Metode ARAS, Kredit

\section{PENDAHULUAN}

Teknologi informasi berperan aktif dalam memperingan pekerjaan pengguna, khususnya dalam pertukaran informasi. Pertukaran informasi membantu pengguna untuk mengambil keputusan yang akurat. Pengambilan keputusan akan akurat apabila didukung dengan data dan informasi yang lengkap.

Model metode pengambilan keputusan salah satunya adalah Multi Criteria Decision Making (MCDM). Salah satu metode sistem pendukung keputusan (SPK) pada MCDM yaitu Additive Ratio Assessment (ARAS) [3]. Perangkingan Metode ARAS dilakukan dengan membandingkan nilai setiap kriteria pada masing-masing alternative dengan melihat bobot masing-masing untuk memperoleh alternative yang ideal [9].

Pada penelitian ini menggunakan data pengajuan pinjaman koperasi. Kemampuan metode dalam menghasilkan alternative ideal menjadi latar belakang penelitian ini untuk menentukan penerima pinjaman koperasi untuk menghindari kredit macet. Diharapkan informasi yang dihasilkan sistem pendukung keputusan dapat digunakan untuk mendukung pengambilan keputusan pengajuan pinjaman.

\section{PENDAHULUAN}

\section{A. Sistem Pendukung Keputusan} (SPK)

Sistem Pendukung Keputusan (SPK) atau Decision Support System (DSS) merupakan suatu pendekatan (atau metodologi) untuk mendukung pengambilan keputusan. Metode SPK menggunakan perhitungan matematis untuk menghasilkan informasi berupa peringkat alternative yang ideal [9]. SPK merupakan sebuah model dengan sekumpulan prosedur untuk pengolahan data dan penilaian untuk mendukung pengambilan keputusan [7]. SPK selain sebagai alat bantu pengambilan keputusan, 
tetapi juga dapat mempercepat penggabungan proses pengambilan keputusan dari beberapa ahli [2]. SPK memiliki dua komponen utama yaitu alternative dan kriteria serta komponen bobot untuk menguatkan dan melemahkan pengaruh kriteria terhadap keriteria yang lain [15]. Proses SPK terdiri dari alternative atau sebagai pilihan dan kriteria sebagai data atau parameter yang diolah untuk memcahkan masalah [3].

\section{B. Additive Ratio Assessment (ARAS)}

ARAS merupakan metode yang didasarkan pada prinsip intuitif bahwa alternatif harus memiliki rasio terbesar untuk menghasilkan solusi yang optimal [3]. Metode ARAS melakukan perangkingan dengan membandingkan nilai setiap kriteria pada masing-masing alternative dengan melihat bobot masingmasing untuk memperoleh alternative yang ideal [9]. Pada metode ARAS nilai fungsi utilitas yang menentukan efisiensi relatif kompleks dari alternatif yang layak berbanding lurus dengan efek relatif dari nilai dan bobot kriteria utama yang dipertimbangkan penentuan alternative terbaik [12]. ARAS didasarkan pada argumen bahwa permasalahan yang rumit dapat dipahami dengan sederhana menggunakan perbandingan relatif. Pada ARAS, rasio jumlah nilai kriteria yang dinormalkan dan ditimbang, yang menggambarkan alternatif yang dipertimbangkan, dengan jumlah nilai kriteria normal dan tertimbang, yang menggambarkan alternatif yang optimal [10]. Dalam pendekatan klasik, metode pengambilan keputusan multi-kriteria fokus pada peringkat. Metode MCDM membandingkan nilai fungsi utilitas solusi yang ada dengan nilai solusi alternatif positif yang ideal atau mengambil jarak ke solusi positif dan ideal negatif yang ideal menjadi pertimbangan [4]. Sedangkan metode ARAS membandingkan fungsi utilitas dari alternatif dengan nilai fungsi utilitas yang optimal [4].

Dalam melakukan perangkingan, metode ARAS memiliki beberapa langkah yaitu:

1. Pembentukan Decicion Making Matrix

$$
\begin{gathered}
x=\left[\begin{array}{ccccc}
x_{01} & \cdots & x_{0 j} & \cdots & x_{0 n} \\
\vdots & \ddots & \vdots & \ddots & \vdots \\
x_{i j} & \cdots & x_{i j} & \cdots & x_{n j} \\
\vdots & \ddots & \vdots & \ddots & \vdots \\
x_{n 1} & \cdots & x_{m j} & \cdots & x_{m n}
\end{array}\right] \\
i=m, 0 ; j=1, n \quad(1)
\end{gathered}
$$

Dimana

$\mathrm{m}=$ jumlah alternative

$\mathrm{n}=$ jumlah kriteria

$\mathrm{xij}=$ nilai performa dari alternative $\mathrm{i}$

terhadap kriteria $\mathrm{j}$

$\mathrm{x} 0 \mathrm{j}=$ nilai optimum dari kriteria $\mathrm{j}$

2. Penormalisasian Decision Making Matrix untuk semua kriteria

$$
\begin{gathered}
\bar{x}=\left[\begin{array}{ccccc}
\bar{x}_{01} & \cdots & \bar{x}_{0 j} & \cdots & \bar{x}_{0 n} \\
\vdots & \ddots & \vdots & \ddots & \vdots \\
\bar{x}_{i j} & \cdots & \bar{x}_{i j} & \cdots & \bar{x}_{n j} \\
\vdots & \ddots & \vdots & \ddots & \vdots \\
\bar{x}_{n 1} & \cdots & \bar{x}_{m j} & \cdots & \bar{x}_{m n}
\end{array}\right] \\
i=\bar{m}, 0 ; j=1, \bar{n}
\end{gathered}
$$

3. Menentukan bobot matriks yang sudah dinormalisasi pada tahap 2

$$
\sum_{j=1}^{n} w_{j}=1
$$

4. Menentukan nilai dari fungsi optimum

$$
s_{i} \sum_{j=1}^{n} \hat{x}_{i j} ; \quad i=\overline{0, m}
$$

5. Menentukan tingakatan peringkat

$$
K_{i} \frac{S_{i}}{S_{0}} ; \quad i=\overline{0, m}
$$

Alternatif dengan nilai $K$ terbesar menghasilkan alternative terbaik dan berurutan sehingga menghasilkan rangking.

\section{IMPLEMENTASI}

Implementasi metode ARAS pada data simpan pinjam pada Koperasi 
Pengembangan Rekayasa dan Teknologi, Vol 15, No. 1, Juni 2019, pp 7-11

p-ISSN: 1410-9840 \& e-ISSN: 2580-8850

http://journals.usm.ac.id/index.php/jprt/index

mengikuti alur pada metode penelitian pada Bab 4. Berikut hasil implementasi metode ARAS pada aplikasi berbasis web.

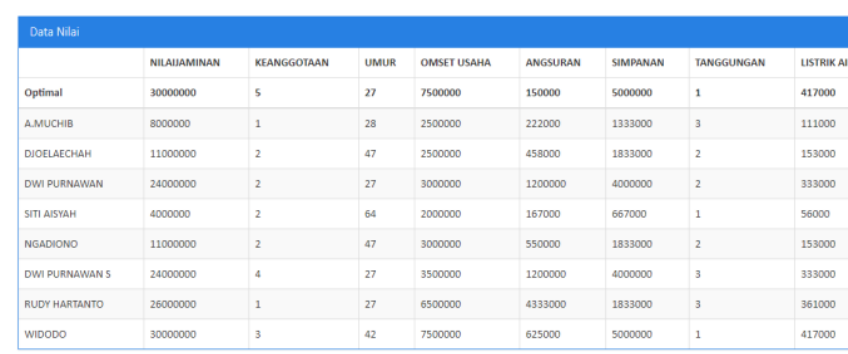

Gambar 1. Implementasi Matriks Decision Making

Gambar 1 adalah hasil implementasi tahap implementasi matrik decision making. Matriks terebut kemudian digunakan untuk mencari matriks normalisasi terbobot.

\begin{tabular}{|c|c|c|c|c|c|c|c|c|}
\hline & 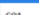 & 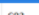 & 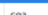 & $m$ & $\cos$ & 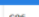 & 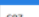 & 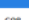 \\
\hline Prioritas & 0.2 & 0.16 & 0.16 & 0.12 & 012 & 0.10 & 0.04 & 009 \\
\hline optimat & 0.179 & 0.27 & 0.139 & 0.197 & 0.27 & 0.196 & 0.1822 & 0.179 \\
\hline A01 & 0.048 & 0.045 & 0.134 & 0.066 & 0.183 & 0.052 & 0.061 & 0.049 \\
\hline $\mathrm{AOZ}_{2}$ & 0.065 & 0.091 & 0.08 & 0.056 & 0.089 & 0.072 & 0.091 & 0.066 \\
\hline A03 & 0.143 & 0.091 & 0.139 & 0.079 & 0.034 & 0.157 & 0.091 & 0.143 \\
\hline ast & 0.024 & 0.098 & 0.059 & 0.053 & 0.243 & 0.0066 & 0.1928 & 0.024 \\
\hline A0s & 0.065 & 0.091 & 0.08 & 0.079 & 0.074 & 0.072 & 0.091 & 0.066 \\
\hline 4006 & 0.143 & 0.182 & 0.139 & 0.092 & 0.034 & 0.157 & 0.061 & 0.143 \\
\hline Aar & 0.195 & cooss & 0.139 & 0.17 & 0.009 & 0.072 & 0.001 & $0.13 \mathrm{~s}$ \\
\hline Aege & 0.079 & 0.130 & 0.09 & 0.197 & 0.008 & 0.198 & 0.197 & 0.079 \\
\hline
\end{tabular}

Gambar 2. Implementasi Fungsi Optimum Gambar 2 adalah hasil penerapan menentukan nilai optimum untuk setiap kriteria dan menentukan nilai matriks ternormalisasi.

\begin{tabular}{|l|l|l|l|l|}
\hline \multicolumn{2}{|c|}{ Perangkingan } & Total & $\begin{array}{c}\text { Fungsi } \\
\text { Optimal }\end{array}$ & Rank \\
\hline Kode & Optimal & 0.196 & 1 & \\
\hline \multicolumn{2}{|c|}{ A } & 0.149 & 0.76 & 1 \\
\hline A06 & DWDODO PURNAWAN S & 0.128 & 0.654 & 2 \\
\hline A03 & DWI PURNAWAN & 0.113 & 0.578 & 3 \\
\hline A07 & RUDY HARTANTO & 0.102 & 0.521 & 4 \\
\hline A01 & A.MUCHIB & 0.081 & 0.412 & 5 \\
\hline A02 & DJOELAECHAH & 0.077 & 0.391 & 6 \\
\hline A04 & SITI AISYAH & 0.077 & 0.39 & 7 \\
\hline A05 & NGADIONO & 0.077 & 0.39 & 8 \\
\hline
\end{tabular}

Gambar 3 Implementasi Fungsi Optimal dan Hasil Perangkingan

Implementasi fungsi optimal dan hasil perangkingan ditunjukan pada gambar 3 . Nilai Optimal menjadi dasar dalam menentukan perangkingan. Hasil implementasi ARAS menujukan alternative 8,6 dan 3 menjadi tiga peringkat teratas dengan nilai optimum $0.76,0.654$ dan 0.578 .
Hasil implementasi metode ARAS kemudian dibandingkan dengan data sekunder yang diperoleh dari Koperasi. Korelasi Rank Spearman digunakan untuk menetukan tingkat kesesuaian atau validasi metode ARAS pada koperasi simpan pinjam.

Tabel 1. Korelasi Spearman Rank

\begin{tabular}{|c|c|c|}
\hline Data & ARAS & Selisih \\
\hline 5 & 5 & 0 \\
\hline 7 & 6 & 1 \\
\hline 4 & 3 & 1 \\
\hline 8 & 7 & 1 \\
\hline 6 & 8 & 4 \\
\hline 3 & 2 & 1 \\
\hline 2 & 4 & 4 \\
\hline 1 & 1 & 0 \\
\hline \multicolumn{2}{|c|}{ Validasi Spearman Rank $=$} & 0.857142857 \\
\hline
\end{tabular}

Hasil korelasi Spearman Rank adalah 0.8571. Korelasi diperoleh dari membandingkan rangking yang dihasilkan oleh data sekunder dengan rangking yang dihasilkan metode ARAS. Dengan hasil 0.8571 menunjukan metode ARAS memiliki kesesuain yang baik karena nilai mendekati nilai sempurna atau nilai 1 .

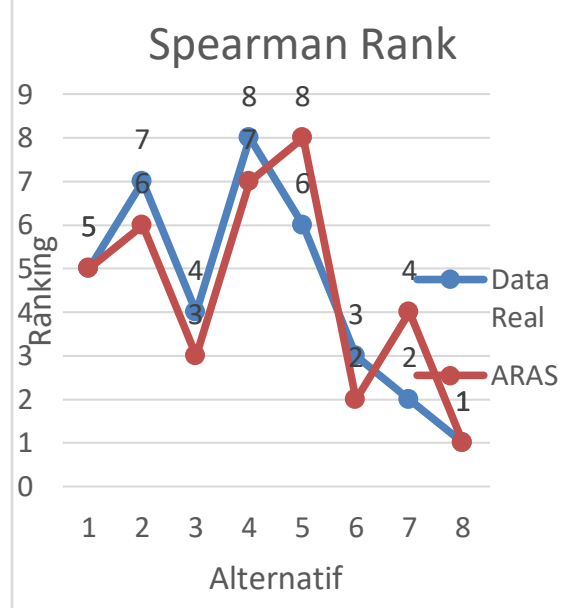

Gambar 4. Grafik Korelasi Spearman Rank Grafik hasil korelasi pada gambar 4 menunjukkan dua alternative memiliki rangking yang sama antara data sekunder dengan ARAS. Sedangkan alternative lain memiliki jarak satu peringkat. 


\section{KESIMPULAN}

Berdasarkan hasil penelitian dan pembahasan dapat ditarik kesimpulan sebagai berikut:

1. Terbentuknya model sistem pendukung keputusan penentuan anggota koperasi potensial dalam pengajuan pinjaman untuk menghasilkan informasi penentuan anggota koperasi yang lolos untuk mendapatkan pinjaman.

2. Model sistem pendukung keputusan dengan metode ARAS memiliki tingkat kesesuaian yang baik dalam penetuan pinjaman yang akan terhindar dari kredit macet.

\section{REFERENCES}

[1] Büyüközkan, G., Göçer, F., 2018. An extension of ARAS methodology under Interval Valued Intuitionistic Fuzzy environment for Digital Supply Chain. Appl. Soft Comput. 69, 634654.

[2] Gaol, L.C.L., Hasibuan, N.A., 2018. SISTEM PENDUKUNG KEPUTUSAN PEMILIHAN TEAM LEADER SHIFT TERBAIK DENGAN MENGGUNAKAN METODE ARAS STUDI KASUS PT. ANUGRAH BUSANA INDAH 13, 6 .

[3] Keršulienè, V., Turskis, Z., 2014. An Integrated Multi-criteria Group Decision Making Process: Selection of the Chief Accountant. Procedia - Soc. Behav. Sci. 110, 897-904. https://doi.org/10.1016/j.sbspro.2013.1 2.935

[4] Koçak, S., Kazaz, A., Ulubeyli, S., 2018. Subcontractor selection with additive ratio assessment method. J. Constr. Eng. Manag. Innov. 1, 18-32. https://doi.org/10.31462/jcemi.2018.0 1018032

[5] Kutut, V., Zavadskas, E.K., Lazauskas, M., 2014. Assessment of priority alternatives for preservation of historic buildings using model based on ARAS and AHP methods. Arch. Civ. Mech. Eng. 14, 287-294. https://doi.org/10.1016/j.acme.2013.10 .007

[6] Kutut, V., Zavadskas, E.K., Lazauskas, M., 2013. Assessment of Priority Options for Preservation of Historic City Centre Buildings using MCDM (ARAS). Procedia Eng. 57, 657-661. https://doi.org/10.1016/j.proeng.2013. 04.083

[7] Nuraeni, F., Purnama, U.F., 2015. Sistem Pendukung Keputusan Pemberian Kredit Usaha Rakyat (KUR) Menggunakan Metode Weighted Product. Konf. Nas. Sist. Inform. 6.

[8] Pinem, A.P.R., Pungkasanti, P.T., Widodo, E., 2017. IMPLEMENTASI PROFILE MATCHING UNTUK PEMBERIAN KREDIT KEDUA PADA KOPERASI SIMPAN PINJAM. Simetris J. Tek. Mesin Elektro Dan Ilmu Komput. 8, 539. https://doi.org/10.24176/simet.v8i2.13 66

[9] Susanto, H., 2017. PENERAPAN METODE ADDITIVE RATIO ASSESSMENT(ARAS) DALAM PENDUKUNG KEPUTUSAN PEMILIHAN SUSU GYM TERBAIK UNTUK MENAMBAH MASA OTOT $12,5$.

[10] Turskis, Z., Zavadskas, E.K., 2010a. A Novel Method for Multiple Criteria Analysis: Grey Additive Ratio Assessment (ARAS-G) Method. INFORMATICA 21, 597-607.

[11] Turskis, Z., Zavadskas, E.K., 2010b. A new fuzzy additive ratio assessment method (ARAS-F). Case study: The analysis of fuzzy multiple criteria in order to select the logistic centers location. Transport 25, 423-432. 
Pengembangan Rekayasa dan Teknologi, Vol 15, No. 1, Juni 2019, pp 7-11

p-ISSN: 1410-9840 \& e-ISSN: 2580-8850

http://journals.usm.ac.id/index.php/jprt/index

https://doi.org/10.3846/transport.2010. 52

[12] Zavadskas, E.K., Turskis, Z., 2010. A new additive ratio assessment (ARAS) method in multicriteria decisionmaking. Technol. Econ. Dev. Econ. 16, 159-172.

https://doi.org/10.3846/tede.2010.10 